\title{
Social innovation and university intellectual property: insights from the UK and Mexico
}

\author{
Dr Ana Alba Betancourt \\ Dr Enrico Bonadio \\ Dr Luke McDonagh
}

Table of Contents

Introduction

What are the key principles found in UK university IP policies?

Mexico - the current status of innovation and IP policies in Mexican universities

Conclusion

E.I.P.R. 2020, 42(5), 293-304

\begin{abstract}
University intellectual property (IP) policies, and the accompanying strategies for incubation of IP via licensing and spin-outs, have not received much analysis from academic lawyers. Moreover, despite several successful examples of universities in the UK generating income from IP, not much is known about how transferable the UK model is when considered in the light of a middle-income developing economy such as Mexico. In this article we analyse critically some of the key tenets of IP policies at universities in the UK to identify what the key legal principles underpinning university innovation and commercialisation are. We consider the potential application of these principles in Mexico, where so far only a limited number of universities have developed IP policies and strategies in line with the incubator model. We explain how universities in Mexico could implement these research findings in their own IP policies. We contend that the mere provision of an IP policy is not a
\end{abstract}


panacea-on its own it is insufficient for ensuring technology transfer and it may even encourage unnecessary patenting. Further investment in infrastructure and in establishing a culture of incubation and entrepreneurship is essential.

\section{Introduction}

The public role that universities play within society is indisputable. University-led research can prove valuable for tackling societal problems, including those related to the environment, social care and public health. ${ }^{1}$ Likewise, when public universities create research that is potentially of commercial value, it is logical that this innovative research should benefit the public. ${ }^{2}$ When considering how best this can be achieved, it is imperative to examine the appropriate role for intellectual property (IP) rights, such as copyright, trade marks, trade secrets, and, especially, patents (since patenting is the primary method of protection for scientific inventions). It is further necessary to assess the most common methods of IP commercialisation: (1) the licensing of IP to external companies; and (2) the setting up of spin-out companies to manufacture, market and distribute products and services. ${ }^{3}$

UK university IP commercialisation revenues have been growing steadily in recent years - the overall annual total for UK universities' IP revenues amounts to more than $£ 150$ million. ${ }^{4}$ Yet, it is worth noting that this success has been uneven, with a relatively small number of large researchintensive universities achieving the most lucrative successes, while the majority of institutions focus on more modest efforts. ${ }^{5}$

Nonetheless, even modest successes are welcome because the commercialisation of IP provides universities with an additional source of income that can be used to fund further research and development. Inevitably this process also has the long-term effect of deepening universities' links with the private sector within the economy-a move 
that brings opportunities but also significant challenges at a time when UK higher education is more market-driven, and more under pressure from market forces, than ever before. ${ }^{6}$

In light of this, it is crucial to ask a series of questions about the relationship between university IP commercialisation and innovation in the wider economy. What are the key legal principles embedded within UK university IP policies? What happens to university IP once it reaches the commercial stage $?^{7}$ In particular, how do public institutions such as universities deal with issues of commercial risk in the investment context? And if UK university IP commercialisation is a success-story, can developing and middle-income countries-taking Mexico as an example - utilise IP policies to encourage university innovation as a tool of development?

In answering these questions, our aim is to analyse comparatively IP policies, knowledge-exchange initiatives and commercialisation strategies in the UK and Mexico. We seek to shed light on university innovation in the UK and to evaluate what steps Mexico could take in developing IP policies and strategies for bringing research outcomes to society, linking universities' innovative research centres with the local economy. In providing this analysis we draw upon existing literature, analysis of the IP policies of 10 major UK universities, ${ }^{8}$ and comments raised at two knowledge-exchange fora we held at Universidad Nacional Autónoma de México (UNAM) in Mexico City (during May 2018 and May 2019) that featured members of the Mexican Social Innovation Network (which included government representatives from the science and technology ministries, scientists, and tech transfer officers from Mexico's major universities, including UNAM and Instituto Tecnológico y de Estudios Superiores de Monterrey (ITESM) (known also as Tecnológico de Monterrey).

In our conclusion we argue that, despite challenges and potential pitfalls, the use of university IP continues to provide significant benefits to universities in the UK, as well as the wider economy, especially where 
the focus of university IP strategies is towards social enterprises rather than towards profit-driven companies. We highlight lessons that can be drawn from successful case studies in the UK, but identify specific issues that must be examined and dealt with in light of Mexico's individual circumstances. We consider elements that might form the basis of the development of an IP policy for Mexican universities designed to promote social innovation in the local economy, currently a priority for UNAM and other Mexican institutions.

\section{What are the key principles found in UK university IP policies?}

The first task that any university must do if it seeks to commercialise its research is to develop an IP policy. The content of such policies is therefore crucial. We examined a sample of 10 UK university IP policies at research-intensive institutions based on documents predominantly available on university websites. ${ }^{9}$ Drawing on these policies, we outline here the main principles and provisions of a typical IP policy at a UK university.

\section{IP ownership and confidentiality}

Providing clarity on IP ownership is a key function of a university IP policy. Invariably, a university asserts in its IP policy (and usually in its employment contracts) that as a general principle it owns all IP generated by university staff. ${ }^{10}$ This is a standard term common to all 10 university policies surveyed. Despite its ubiquity, there are exceptions to this term. Non-staff, such as postgraduate research students (for example $\mathrm{PhD}$ candidates) are usually in a different position - they may sign up to specific terms about IP ownership as a condition of their enrolment. ${ }^{11}$ Typically, universities assert ownership of IP in cases where the students are working in collaboration with university staff or as part of a funded project. ${ }^{12}$ With respect to undergraduate and taught postgraduate students, universities generally do not claim ownership of IP created by them, except where they negotiate and agree otherwise. 
Generally, academic publications are of little commercial value; therefore UK universities generally waive rights over the copyright in scholarly publications written by academics to pursue their careers, provided that the material does not form part of a course or teaching materials for the university; however, the university may assert rights in underlying research/materials upon which the scholarly work is based, including software, data, databases, designs and patentable inventions. ${ }^{13}$

Ensuring confidentiality is also a paramount aim of university IP policies (present in all 10 policies examined). University researchers are typically under an obligation to guarantee secrecy before filing patent applications (aiming to safeguard the novelty of the invention and thus, its patentability) ${ }^{14}$ Since this goes against academic instinct to publish and present results as quickly as possible, it is crucial that universities inform their researchers about this obligation.

Similarly, transfer of any valuable university know-how - such as trade secrets - should always be covered by an adequate confidentiality agreement. Where a patent application is being contemplated concerning an invention disclosed in a thesis, regardless of ownership, then external examiners/reviewers are typically asked to sign a confidentiality undertaking. It may also be necessary for the thesis to be held in the university library on a restricted access basis until a patent application has been filed. ${ }^{15}$

\section{The role of the Technology Transfer Office (TTO)}

The university TTO is the initial place researchers go to in order to obtain advice on IP. This includes assessments to identify projects early on and advise on what may be patentable or protected by copyright, what may be kept as a trade secret, and what is required for branding (trade marks), etc. ${ }^{16}$ Researchers should: (1) assist in protecting university rights to the IP by keeping suitable records of creation wherever possible; (2) obtain 
advice in relation to any invention of a technical nature, which might be protected by a patent, from the TTO to avoid any premature disclosure which may reduce the commercial impact; (3) be prepared to discuss the invention or IP, its nature and applications with third parties subject to a confidentiality agreement, during the assessment or commercialisation process. ${ }^{17}$ The active participation of the inventor(s) in the commercialisation of IP is often necessary for a successful outcome.

\section{Commercialisation procedures, risk and governance}

How do university IP policies envisage commercialisation? There are two principal ways: (1) facilitating a licence to an already established company in return for a fee or royalties; or (2) setting up a spin-out company as a vehicle for commercialisation such as the marketing and distribution of goods and/or services. ${ }^{18}$

Licensing is reasonably straight-forward and generally risk-free for universities: the university simply agrees a contract with a private company specifying the IP, the uses, the period of the licence term, and the fee/royalty rate for use. However, establishing a spin-out company is more onerous. It entails the creation of a new company whose main target is the development and exploitation of university IP. Such company may seek investors who would subscribe for shares. Most UK universities are public institutions and many have limited experience of the kinds of risktaking investment common in the private sector. So how does a university decide how to assess the risks of setting up a new spin-out company?

A research-intensive university with an interest in commercialisation usually features an entity equivalent to a university "IP Commercialisation Board" or an "IP \& Licensing team" (as it is known at KCL) - or in some cases, e.g. Oxford, UCL, Cambridge, etc., via a subsidiary entity such as Oxford Innovation Ltd, UCL Business, or Cambridge Enterprise. 
The IP Commercialisation Board, or equivalent, is responsible for making recommendations concerning all transactions relating to spin-out companies, pending final approval by senior university authorities/committees/senates. In light of the risks involved (financial, reputational, etc.) should the venture not be successful, in deciding whether to approve the creation of a spin-out company the IP Commercialisation Board will weigh up a series of key factors, including: (1) the overall benefit to the university; (2) the nature and value of the IP to be vested in the company; (3) the viability of the business plan; (4) the university's interests (e.g. risk, financial cost, opportunity cost, tax, etc.); (5) insurance cover; (6) legal agreements for securing funding; (7) availability of an appropriate management team; (8) any external partner organisation's reputation, financial position, contribution (e.g. equity holders/collaborators/funders); and (9) whether to grant the spin-out access to university staff and facilities through contracted service agreements (or R \& D contracts). ${ }^{19}$

Risk is a fundamental issue as universities can be reluctant to put forward initial capital. Unless external investors agree to provide "seed investment", this element of risk - where the university must invest its own funds - can lead to what is sometimes referred to as "valley of death": the failure to obtain sufficient funds to develop the spin-out. This problem is well known and has been the subject of discussions in the UK Parliament. ${ }^{20}$ It reflects the tension between UK universities as essentially public entities reliant on student fees and public research income, versus their involvement in the private sphere (the free market), where investments in spin-out companies may result in significant economic gains or losses.

In terms of governance, for spin-outs a university researcher/inventor may participate as an executive or non-executive director, employee of, or service provider to the company, subject to university approval and any conflicts of interest being identified and mitigated. ${ }^{21}$ The university typically reserves the right to appoint, remove or replace a director of its choice to the spin-out company's board of directors, or to have an 
observer at board meetings. ${ }^{22}$ If the university director leaves the university, it is expected they should resign from the board of the company. ${ }^{23}$ The incorporation documents of the spin-out company should provide appropriate mechanisms for managing potential conflicts of interest.

Where universities intend to take a shareholding in the new spin-out company, the university is usually a minority shareholder. ${ }^{24}$ The IP Commercialisation Board (or equivalent) will monitor university investment in these companies and make recommendations to university management concerning decisions regarding any sale of equity. In this way, university IP policies envisage conflicts of interest in the commercial context being managed appropriately. ${ }^{25}$ Other potential conflicts need to be managed as well. For example, academic researchers have an interest in disseminating the results of their research, e.g. via publication in journals, but this may collide with the business interests of a company. Take for example a scenario where a university researcher comes up with a potentially valuable invention and is simultaneously a manager of a spin-out company. The researcher's first instinct may be to publish an academic paper in, e.g., Science or Nature as soon as possible. Yet, as a manager within a company that could exploit the invention, the researcher is supposed to consider those interests as well. Therefore, what the researcher ought to do to manage this conflict of interest is to delay publication of his/her research until the IP issue has been resolved, e.g. by filing a patent application.

\section{Revenue-sharing}

It is vital that university IP policies explain the extent to which researchers can benefit financially from IP commercialisation. In all 10 university policies examined it is stated that a percentage of any net revenue generated from the commercial exploitation of IP is shared by the university with the inventor/creator. ${ }^{26}$ Percentages can vary from institution to institution and depending on the size of the overall revenue, 
but as they are designed to incentivise staff to commercialise IP they are usually quite generous. The KCL policy provides that researchers are entitled to 90 per cent of the first $£ 10,000$ net revenue and 70-50-33 per cent on a sliding scale thereafter as revenues increase. ${ }^{27}$ At Oxford researchers are entitled to 85.7 per cent of net revenue up to $£ 50,000$, but a smaller share as the overall income increases. ${ }^{28}$ At UCL researchers receive 80 per cent of the first $£ 100,000$ of net revenue, and a small share of increasing revenues thereafter ${ }^{29}$; meanwhile, at Cambridge the policy is slightly more generous than UCL-researchers are given 90 per cent of the first $£ 100,000$ net revenue and a smaller share of additional revenue above this amount. ${ }^{30}$

Moreover, students - such as $\mathrm{PhD}$ candidates - are also entitled to receive a percentage of net revenues should they contribute to generate IP. ${ }^{31}$ Students are typically given the same treatment as any other university IP creators in terms of percentages - in other words the university does not discriminate based on whether IP is created by experienced academics or young research students.

\section{How does commercialisation occur? UK University spin-out success stories}

Having identified the key principles of university IP policies, it is now time to turn to the issue of how IP commercialisation occurs in terms of impact/links with the private sector. Empirical research by Dahlborg et al. demonstrates that "small and medium-sized companies are the largest absorbers of academic patents". ${ }^{32}$ Given the centrality of SMEs to all modern economies this fact is significant. Furthermore, some of these SMEs are university spin-outs operating as social enterprises - a type of company that differs from other categories of businesses, because these entities are not entirely profit-driven. ${ }^{33}$ Focusing on their public/social oriented goals, social enterprises exist to commercialise university IP with revenues gained from IP being reinvested in the social enterprise, creating greater opportunities for public benefit. ${ }^{34}$ 
So, what are examples of successful UK university spin-outs? Taking the field of robotics as one example, the two leading UK robotics spin-out companies are Consequential Robotics (a spin-out from the University of Sheffield ${ }^{35}$ and Oxbotica (a spin-out from the University of Oxford). ${ }^{36}$ Consequential Robotics develops companion and assistive robotic systems that enhance quality of life as people age (e.g. companion robots). Oxbotica works to develop the next generation of autonomous vehicles. Both of these prominent spin-outs have benefited not only from the provision at the university level of a clear IP policy that facilitates the sharing of revenue between university and individual researchers, but also from the commercialisation strategies that underpin spin-outs. Clear contracts were drawn up between university and spin-out company. In each case the university was willing to provide organisational and financial support to these companies as they were getting started. The university then benefits from revenues flowing back into further university R \& D.

There are several other examples. The University of Oxford created in 2005 a company called Oxford Nanopore Technologies Ltd, which produces and sells nanopore sequencing products, with the company's value recently reaching $£ 1.5$ billion. ${ }^{37}$ The University of Cambridge has also given birth to successful spin-outs. It created Congenica, which has launched a platform that highlights genetic disorders and rare diseases: in 2015 it was awarded $£ 2$ million by Genomics England to continue its research. ${ }^{38}$ Cambridge University also spun-out Lycotec, a biotech company famous for its "anti-aging" chocolate bar. ${ }^{39}$ English universities other than Oxbridge are also very active when it comes to generating spinouts. UCL and Imperial College, for example, created in 2015 Bio Nano Consulting, known for coming up with a $£ 10$ device that monitors kidney disease. ${ }^{40}$ Spirogen is another company created by UCL in 2001, which develops antibody-drug technology aimed at treating cancer tumours. The company was then bought by AstraZeneca in 2013 in a $\$ 440$ million deal. ${ }^{41}$ One of City, University of London's most successful spin-outs is Zenoot, which operates in the field of compressor technology. ${ }^{42}$ And the 
University of Manchester has spun-out C4X Discovery, which develops technology producing 3D structures of drug molecules, facilitating rapid, safe and cost-effective development of drugs. ${ }^{43}$

Wales and Scotland also provide a fertile ecosystem where spin-out ventures have been successful. In 2009 the Welsh Institute for Minimal Access Therapy at the University of Cardiff created Ultravision, a company which has developed a device capable of handling the smoke during keyhole surgery in the abdomen. The product is distributed in 25 countries around the world. ${ }^{44}$ The University of Edinburgh created NuCana Biomed which produces anti-cancer therapies. In 2011 the company secured $£ 6.74$ million in Series A venture capital financing. ${ }^{45}$ A Series A investment was also secured by Clyde Biosciences, a company created in 2012 by the College of Medical Veterinary and Life Science at Glasgow University, which has developed innovative technology to assess drug toxicity for biotech and pharma companies. It obtained a $£ 2$ million Series A investment led by Epidarex Capital, a life science venture capital fund. ${ }^{46}$ And the University of Dundee has spun-out Exscientia, which uses artificial intelligence to discover more effective drugs. This spin-out recently partnered with the US biopharma company Celgene, which contributed a $£ 19$ million upfront investment. ${ }^{47}$

The above success stories confirm that the commercialisation of academic innovation does produce tangible results, which benefits both investors and universities themselves, as revenues are typically reinvested to fund and support further university research. More broadly, the whole process has the effect of strengthening universities' ties with the private sector. While this undoubtedly changes the traditional public role of the UK university, it does have benefits for the local and national economy, and accordingly, to wider society and the public at large.

\section{Mexico - the current status of innovation and IP policies in Mexican universities}


Recognising the potential for economic and societal benefits, the Mexican Government has in recent years sought to encourage its universities to commercialise university innovation through licensing and spin-outs, particularly in the areas of science and engineering. In this vein, the Mexican Government agencies of Science and Technology helped establish a "Red de Oficinas de Transferencia de Tecnología" (a network for the Universities and Research Institutes Technology Transfer Offices) and a "Red de Innovación Social" (Mexican Social Innovation Network) to try to encourage the transfer of technology.

Given the proven link between university patents and SMEs, ${ }^{48}$ improving the knowledge transfer mechanisms in Mexico between universities and the private sector could lead to a boost for Mexico's SME sector, as well as providing universities with IP revenue. Yet, although there are some notable positive exceptions, in general Mexican universities have yet to develop successful IP policies and strategies. ${ }^{49}$

In Mexico, the core aims of universities are traditionally understood to be research, education and the dissemination of culture. ${ }^{50}$ This means that commercial exploitation of research outcomes is not seen as a priority; indeed, commercialisation is sometimes even viewed as being contrary to the goals of universities in Mexico (especially in public universities where it is expected that all research outcomes should be made accessible to the public) ${ }^{51}$ Despite this, the above UK examples demonstrate that public universities can use the revenues from IP commercialisation to fund further public-focused research - a point which indicates that there are ways to manage the public-private relationship. ${ }^{52}$

Furthermore, Mexican universities are expected, as part of their public role, to contribute to the technical and economic development of the wider country. ${ }^{53}$ The creation of TTOs helps to achieve this, which inevitably brings IP issues into play. In this vein, Calderón-Martínez and GarcíaQuevedo argue that Mexican universities should define their IP policies in accordance with best practices elsewhere, as this is likely to facilitate research agreements and the protection of innovative outcomes from 
research, as well as the distribution of the benefits obtained by the commercial exploitation of the creations. ${ }^{54}$ They further argue that universities should enhance collaboration with the private sector, in order to maximise the benefits stemming from academic patents and transform research into industrial innovation. ${ }^{55}$ At present, the Mexican Science and Technology Council co-ordinates the TTO network in the country. However, Mexican TTOs typically lack sufficiently defined IP policies and strategies to facilitate adequate agreements between inventors, authors, entrepreneurs, employees or students at the university (questions of how to deal with resources provided by third parties also arise).

Given the lack of publicly available IP policies and strategies at the time of writing, to provide the most accurate overview possible we examine here: (1) the overall regulatory framework of Mexican laws covering university innovation at present, including labour and employment laws; (2) two case studies: (a) the Instituto Tecnológico y de Estudios Superiores de Monterrey (ITESM) University IP policy; and (b) the policies of the Government of the state of Jalisco to encourage university innovation. Finally, we highlight the main issues and challenges for IP commercialisation at universities in Mexico and make suggestions regarding how best to tackle them, taking into consideration the UK experience.

\section{Regulatory framework}

Mexican IP national law has been greatly influenced by international agreements such as the North American Free Trade Agreement (NAFTA) and the WTO TRIPS Agreement. ${ }^{56}$ According to Aboites, these treaties produced three major changes to Mexican IP law: (1) there was an expansion of the definition of patentable knowledge; (2) influence was taken from US IP jurisprudence, which has tended to strengthen protection of IPRs; and (3) there was a shift from the open science model to one based on the commercialisation of research results at the public universities. $^{57}$ 
The legislative changes enacted in Mexico after TRIPS have favoured the production of academic patents in Mexico. On the face of it, this could be viewed as progress. ${ }^{58}$ However, an increase in academic-related patents would not per se be beneficial to the wider society unless these patents (and the protected technologies) are actually transferred to the local economy. Unfortunately, inefficient patenting often occurs in Mexicofor instance, UNAM is one of the most significant Mexican patentees judged by applications to IMPI, yet despite the large number of patents granted each year, very few are licensed or spun out into the local economy. ${ }^{59}$ One cause of this failure is said to be the lack of an "IP culture" as well as a lack of domestic legislation for regulating the outcomes of research activity at universities. ${ }^{60}$

In the absence of a comprehensive regulatory approach there exists a patchwork of different national laws governing the transfer of technology in Mexico. The first of these is Mexican Labour Law. Under Mexican IP law, inventions that arise in a working relationship - such as between a university employer and its researchers/employees - are regulated by labour law. The Mexican Labour Law has three different rules for the exploitation of inventions: (1) the name of the inventor shall be acknowledged; (2) when the worker does research paid by the enterprise, the property of the invention (including the right to exploit) will be the employer's; the worker will nonetheless have the right to receive compensation supplementary to his salary, but only when the economic benefits of her invention are proportionally higher than her salary; and (3) in any other case the IP rights over the invention will be owned by the people that made it (the employer will only have preferential right to the exclusive use of the invention, or acquisition of the relevant rights).$^{61}$ The above rules fail to define comprehensively the scope of the relationship between researchers and universities - e.g. applying rule (2) strictly to researchers could mean that they would never be able to hold economic rights over their inventions and would only receive compensation when the invention's economic benefits reach a relatively high level. Therefore, if the relationship between researchers and universities were only ruled by the current labour law rule (instead of, e.g., by an IP policy that 
provides rules for management of royalties) the result would be a lack of incentives for Mexican academics to protect and exploit the outcomes of their work.

Article 13 of the Science and Technology Law in Mexico is also relevant here. This law states that scientific and technological education is intended to be linked with the productive industries and the services sector, in line with the Mexican Federal Government's efforts to support scientific research, technological development and innovation. ${ }^{62}$ Article 14 states that the State Agency CONACYT ${ }^{63}$ is in charge of managing an information system which is intended to (1) be accessible to the general public; and (2) protect IP rights. This has proven to be a challenge in practice, owing to gaps in the knowledge of IP rights within the academic researcher community, and to the failure thus far to build a digital platform containing information comprising the total research outcomes of all the research centres in Mexico. This aspect of the regulatory system is therefore largely ineffective.

A further legal aspect is provided by the Mexican Regulation of the National Researchers System. This system (known by its Spanish language acronym SNI) is also managed by CONACYT. The SNI operates based on a point system for academic career advancement and promotion in five different categories: candidate, level I, II, III and Emeritus. Depending on the ranking, the researcher will have a different economic incentive. The publication of research articles is one key part of the system; however, for our purposes what is crucial is that obtaining a patent ${ }^{64}$ boosts the researcher's status. This has contributed to a rise in academic patenting at Mexican universities. Nevertheless, it also appears to have created a perverse incentive: although TTOs assist Mexican researchers in the filing process, the resulting patents rarely transcend the research stage. Owing to the fact that few university patents are licensed or spun out into new companies, we can conclude that if innovation is meant to operate as a "lifecycle", then the cycle in Mexico has a broken link: there is insufficient activity between academia and the innovative private sector. ${ }^{65}$ 
The final part of patchwork of different national laws governing the transfer of technology in Mexico is as follows: universities that do not have a specific IP policy nevertheless have a duty to try to secure "extraordinary incomes" for their employees. This includes the allocation of royalties derived from commercial exploitation of patented inventions. ${ }^{66}$ For instance, UNAM's relevant regulation specifies that if inventions generate profits, these will be distributed as follows: 20 per cent for the central university; 30 per cent for the centre or institute where the invention was generated. If the invention arises from a collaboration of different research institutes, this percentage will be distributed among them according to their agreement. Finally, 50 per cent of the extraordinary income will be distributed among the inventors. ${ }^{67}$ Yet, complexities arise owing to the organic way projects develop at UNAMthere is not always a previous agreement between the researchers and the institutes whose research outcome becomes protectable by IP. The lack of such agreements is indicative of a lack of organisation with respect to the commercialisation of inventions.

In the absence of a specific university IP policy, the above-portrayed regulations have a direct impact on the protection and exploitation of inventions. Yet, there are two exceptional case studies that are worth examining. The first concerns one of the most important private universities in Mexico, Instituto Tecnológico de Estudios Superiores de Monterrey (ITESM), which has developed a detailed IP policy in order to encourage commercialisation via an incubation model. The second concerns the local government of the state of Jalisco, which has developed specific policies to encourage the functioning of the IP innovation ecosystem within its territory.

\section{Case studies}

- Mexican case study 1: the RESPITA model at Instituto Tecnológico y de Estudios Superiores de Monterrey (ITESM) 
ITESM (known also as Tecnológico de Monterrey) is a private university found in 1943 in Mexico. It is currently one of the top five universities in Latin America. It has built an education model called "Modelo Tec21" that promotes entrepreneurship with a social perspective $.^{68} \mathrm{Cantu}-\mathrm{Ortiz}$ et al. note that the RESPITA (Research-Ecosystem-PeopleIntellectualProperty-Transfer-Alignment) model put into place at ITESM during 2010-15 encouraged the launch of 16 small companies and supported 32 IP applications (most of which were for patents). ${ }^{69}$ While the model was therefore a moderate success, Cantu-Ortiz et al. identify two key flaws centring on the specifics of the IP policy in question (which was put into place in 2007): a lack of clarity on revenue-sharing and insufficiently detailed info on resolving potential conflicts of interest. Cantu-Ortiz et al. remark:

"For example, although inventor ownership rights encourage more faculty entrepreneurship ... the 2007 policy stipulated that the technologies developed at the university belonged to the institution and that only $30 \%$ of patent royalties would be awarded to researcher-inventors. The policy did not consider potential conflicts of interest for professors where both inventors of intellectual property and equity-holders in a new spin-off company. It also limited the university's flexibility to reap financial returns through technology transfer. This means that the university could not hold equity in spin-off companies and could only recuperate its investment in the incubation cells through licensing fees." 70

Cantu-Ortiz et al. note that a recent IP policy change at ITESM gives a larger share or benefit to inventors:

- "According to the new program, the university provides research and development funding to an inventor and retains rights to just $50 \%$ of the royalties (down from 70\%) generated from intellectual property licenses. The TTO has made new financial arrangements that allow it to hold a share of equity in university spin-offs, and it negotiates for some percentage of equity in the spin-offs it assists." 71 
Ultimately, Cantu-Ortiz et al. remark upon a key point that sums up the difficulties with turning patent applications into successful examples of technology transfer in Mexico:

- "Just as in developed economies, an intangible resource-entrepreneurial culture-- was key for entrepreneurs in Mexico; in fact, it was the most important resource." 72

Developing an IP policy is the first step towards developing this entrepreneurial culture at universities - but by itself it is insufficient. Structures must be put in place to incubate and facilitate an open, transparent and supportive process for the commercialisation of IP, whether via licensing or spin out. University incubators of the kind several UK academic institutions have created could provide useful examples for development in this regard.

\section{- Mexican case study 2 -innovation policy in the state of Jalisco}

Jalisco is a region of 8.2 million people in the centre-west of Mexico. It is known around the world for being the birthplace of Tequila and Mariachi. ${ }^{73}$ In 2000, Jalisco's State Government created the Local Science and Technology Council to develop its innovation ecosystem in line with the then current National Development Plan, where the priority areas were those focused on solving social problems, such as health, with the aid of technology.

From informal discussions with Larisa Cruz of the Ministry of Innovation, Science and Technology ${ }^{74}$ we learned that even though the Council was founded in the year 2000, at the time there was an absence of support programmes for promoting IP protection in highly technological sectors. This is why, in 2013, the Ministry of Innovation, Science and Technology of the state of Jalisco was created - with a new law being passed in 2014 to define strategically the paths to enhance innovation. ${ }^{75}$ Government actors in the region have been developing a range of creative clusters in 
the region featuring what is known as the "quadruple helix": academy, industry, society and government. ${ }^{76}$ In particular, the innovation ecosystem has been enhanced by: (1) establishing an open channel of communication between innovation stakeholders and the government, so that the regional government can, where possible, address innovators' needs by reforming the legal framework; and (2) setting up public forums and workshops on IP, and providing personalised IP guidance-e.g. if certain issues turn out to be too complex, researchers can obtain pro bono advice from specialists at AMPPI ${ }^{77}$ ANADE $^{78}$ and IMPI $^{79}$ —all of whom are willing to give advice on how to increase the viability of research projects. These strategies have led to Jalisco being viewed as the "Silicon Valley of Latin America". ${ }^{80}$

The Jalisco Ministry of Innovation has also established three programmes:

- PROPIN: a special programme which aims to promote IP knowledge and use (focusing on inventors, entrepreneurs, SMEs, etc.);

- an enterprise programme which aims to consolidate indicators relevant to enterprises and start-up companies; and

- a universities programme which aims to contribute financially to the annual costs of protecting IP.

It is the third programme that is particularly relevant here. For universities to participate, they must fulfil certain conditions: (1) they must develop a set of rules and norms to regulate IP and commercialisation of inventions (e.g. an IP policy); and (2) they should develop a technology portfolio available for possible investors from the private sector. Moreover, each year the Jalisco Innovation Ministry assesses whether the universities that participate fulfil their commitments. Several private law firms have been integrated into the programme. The Innovation Ministry only allows law firms with offices in Jalisco to participate. The law firms can assist universities in obtaining, licensing and litigating IP. 
The above strategy has been so successful that, in only three years of its application, Jalisco has moved from fifth to second place as of 2019 in the amount of patents registered by a "Local Entity" in Mexico (second only to Mexico City) ${ }^{81}$

After highlighting Jalisco's success story of enhancing the innovation ecosystem in the region, we now proceed to highlight the problems encountered at the broader national level.

\section{Key problems and lessons learned}

In this section we provide general concerns about the current IP regulation at Mexican universities that were expressed by participants at the IP forum events held at UNAM in May 2018 and $2019^{82}$ :

\section{The internal processes of university bureaucracy inhibit IP} commercialisation: excessive bureaucracy tends to discourage the participation of private enterprises and reduces their propensity to collaborate with research centres. Even when private enterprises are interested in collaborating with universities, university processes for issuing contracts make it difficult for agreements to be successfully negotiated.

Opportunity for change: Mexican universities should optimise their internal processes to encourage innovation and commercialisation activity. A key reform - we suggest - would be to restructure the TTOs and incubators as currently formed so that they operate more co-operatively between key departments within the university, featuring IP and business experts. Universities could do much more to maximise their resources - expert researchers from departments such as law (where there is IP expertise), accounting (where there is finance and tax expertise), marketing (where there is sales/branding expertise), administration (where there is business expertise) should be connected with researchers from Science, Technology, Engineering and Mathematics (STEM) where 
researchers are likely to generate patentable research, as well as researchers in the creative faculties such as architecture, design, music, and cinema (where researchers may create copyright works). Furthermore, when universities do not have the resources to invest in spinning-out their promising research projects, they should be open to obtaining external funding from impact investors (this would help the projects to overcome the so-called "valley of death").

2. Lack of IP knowledge: many Mexican university researchers are still not fully aware of the different forms of IP rights available to protect the outcomes of their research and the advantages of commercialisation. There is thus a need to fill that awareness gap, by strengthening the IP culture within the research community.

Opportunity for change: as occurs at UK universities, Mexican universities should use their own resources to provide adequate information and training to researchers, professors and students. This can be achieved through communication strategies, as well as giving courses that provide basic knowledge, awareness of intellectual property rights and their crucial importance. The reforms of the TTOs to link them with experts with relevant knowledge in law, accounting, marketing, etc., can assist the enactment of this change.

3. Lack of incentives: the National Research System (SNI) as currently operative does not provide incentives to researchers to commercialise their research, to (potentially) become entrepreneurs, or even to make their research outcomes available to society in other ways. Researchers are therefore, unlikely to achieve social impact. Researchers typically complain about the amount of administrative work they must do in order to justify their work e.g. having to fill out reports regarding their annual work to several different university administrative offices. 
Opportunity for change: the example of Jalisco should be followed - the local government in Jalisco encourages researchers to commercialise their research and, potentially, to become entrepreneurs, by giving them a sufficient incentive. The SNI could follow this example for all university research in Mexico. Furthermore, part of the administrative burden for researchers should be removed by creating a single, simplified system where researchers can write and submit their annual reports, allowing this to be shared with the evaluation departments within the university and also the national system. In addition to Jalisco, the UK examples cited above can also be studied and applied to the Mexican context.

4. Students: currently the law does not provide for Mexican students - e.g. PhD candidates and postgraduate students - to receive any portion of the revenues generated by the commercialisation of the IP they have contributed to create/invent. Moreover, a patent application can be time-consumingresearchers, especially students, know that it can divert their energies away from continuing their research. Ultimately, this can lead students involved in research projects to look for jobs elsewhere rather than participate in IP applications.

Opportunity for change: as is the case in UK university IP policies, Mexican university IP policies should provide acknowledgement and economic incentives for students involved in research projects. Furthermore, the example of Jalisco may be followed by other local governments: providing a strong support network for researchers, including students, and provide government funding for university IP applications ${ }^{83}$ and follow-on commercial exploitation. This action would encourage researchers to pursue the exploitation of their research outcomes. 
5. Open access: it is widely believed within the Mexican academic community that science and research done in public universities should be accessible as much as possible to the whole population. ${ }^{84}$ This is laudable, but in some cases it seems to have turned academic opinion against the idea of IP exploitation, which precludes the possibility that university innovation can provide revenues for follow-on R \& D.

Opportunity for change: there is a need for an effective and balanced mechanism of making research outcomes accessible to society. IP should not be ruled out, but instead should be considered as potentially of benefit with respect to addressing societal needs as well as university income generation (via e.g. social enterprises). In the UK this is approved on a case-by-case basis, taking into account the special characteristics of the research outcomes involved. Mexican universities may learn from this experience and include in their IP policies mechanisms that ensure appropriate assessments to balance between IP management and open access for research outcomes.

6. Mismanagement of funding: there are concerns about conflicts of interest and even corruption with respect to the management of public funds for innovation at universities and research centres. This potentially affects the allocation and distribution of funds for crucial areas of research. It has further generated a certain reluctance on the part of authorities when it comes to commercialising research outcomes and sharing royalties.

Opportunity for change: Mexican universities should aim in their IP policies to address potential conflicts of interest, taking influence from the way such conflicts are managed at UK universities. Mexican universities should also create an IP Commercialization Committee responsible for monitoring the revenues obtained from shares (when there is a spin-out company involved) and royalties (obtained from licences). The Committee can ensure the terms of 
the licences are in line with the principles of social innovation: community participation, enhancement of social development, etc.

7. Lack of a regulatory framework: there is no all-encompassing Mexican statute that covers university innovation and IP. The introduction of a stronger national legal framework that incentivises researchers, promotes the virtuous "life-cycle" of innovation and boosts the academic community in Mexico is needed. The current legal framework in Mexico does not promote such virtuous circle. ${ }^{85}$

Opportunity for change: the Federal Mexican Government should provide an innovation legal framework, underpinned by a strategy for university innovation. The system must be dynamic so that it can change and adapt according to the needs of the stakeholders of the innovation ecosystems.

\section{Conclusion}

UK universities tend to follow a standard model of IP creation, knowledge transfer, and IP commercialisation, leading to opportunities for spin-out formation and generation of licensing income. Although successes have been unevenly distributed across the sector, it is clear that several research-intensive institutions are utilising IP commercialisation as a way to boost their overall revenues, providing income to fund follow-on R \& D. The UK model is based on two key elements: (1) the provision of clear and precise IP policies; and (2) the promotion of an entrepreneurial incubation culture, including providing access to funding for start-ups, spin-outs or social enterprises, both internally (within the university) or externally (through investment by private companies).

This model does not exist in many institutions in Mexico-as a result there is an overall lack of IP commercialisation, despite high levels of academic/scientific achievement in research at the key national institutions (e.g. at UNAM, ITESM, etc.). In this article we suggest that 
there are positive lessons that can be drawn from UK universities' IP policies. Yet we acknowledge that there are also matters that must be examined and dealt with in light of Mexico's specific circumstances: namely, the issues concerning lack of inclusion of $\mathrm{PhD}$ and postgraduate students in the ownership of IP rights; corruption and bureaucracy; and the adoption of an encouragement/incubator model. A national legal framework that enhances university innovation in Mexico is required. Further to this, a clear and precise IP policy should be developed at each Mexican university, tailored to the specific needs of each institution (rather than exporting wholesale a UK model).

Nonetheless it is clear from the ITESM example explored above that even where there is an IP policy this is by itself insufficient. Without cultural and infrastructural support aimed at developing an "entrepreneurial culture" directed towards solving societal needs, an IP policy is unlikely to lead to success. This shows the fragility of IP law as a framework for incentivising and rewarding creativity-as we note in this article, incentives to patent under the Mexican National Researchers system (SNI) have led to sub-optimal outcomes where many patents are filed and granted to universities, but most of them are never actually transferred into the local economy. For IP to truly benefit the university and society at large, investment is required at an early stage to facilitate networking connections with local investors and entrepreneurs.

In conclusion, considering the above examples and the relevant literature surveyed in the UK and Mexico, a key imperative emerges: the need to facilitate an entrepreneurial culture within the university sector in Mexico. The incubator model-bringing together scientists and engineers, technology transfer officers, managers, lawyers, etc.-can help to facilitate this. It is necessary to build this incubation culture at Mexican institutions from the ground up, considering the characteristics of the local economy. ${ }^{86}$ Jalisco is one state in Mexico where there are signs of success, but other states in Mexico are lagging behind. This trend will only worsen unless legal and cultural reforms are enacted. 
Footnotes

$1 \quad$ K.R. Fabrizio and A. Di Minin, "Commercializing the Laboratory: Faculty Patenting and the Open Science Environment” (2008) 27 Research Policy 914.

$2 \quad$ M. Perkmann and N. Walsh, "Relationship-based university industry links and open innovation: towards a research agenda" (2007) 9 International Journal of Management Reviews 259.

3 S. Öcalan Özel and J. Pénin, "Exclusive or open? An economic analysis of university intellectual property patenting and licensing strategies" (2016) 21 Journal of Innovation Economics \& Management 133; M. Fressoli, E. Around and D. Abrol, "When grassroots innovation movements encounter mainstream institutions: Implications for models of inclusive innovation" (2014) 4 Innovation and Development 277; G. Seyfang, S. Hielscher and T. Hargreaves, "A grassroots sustainable energy niche? Reflections on community energy in the UK” (2014) 13 Environmental Innovation and Societal Transitions 21; D. Hernandez-Sanchez, Jose Luis Leyva-Montiel and M. Angel Perez-Angon, "University-industry collaboration: A successful case in the electronics and software design area in Mexico" (2016) 41 Interciencia 668; N. Hewitt-Dundas, "Profiling UK University Spin-outs" Enterprise Research Centre Paper No.35 (2015), https://www.enterpriseresearch.ac.uk/wp-content/uploads/2015/07/ERCResPap35-M.-Hewitt-Dundas.pdf [Accessed 1 April 2020].

4 HEFCE, Higher Education Business and Community Interaction Survey 2015-16 (October 2017/23): "There has been an increase in total income from IP of 13 per cent, from $£ 155$ million to $£ 176$ million in 2015-16. This includes a 37 per cent rise in IP income from licensing and other sources (but excluding sales of shares). This increase follows a rise of 25 per cent in 2014-15. There are noticeable differences in IP income by partner and type of licence. Large business spending on non-software licences showed another strong increase, growing by 48 per cent to $£ 100$ million. Income from non-software licensing to small-andmedium-sized enterprises (SMEs) also increased strongly, up by 43 per cent on 2014-15, reaching $£ 16$ million." See the webpage at https://webarchive.nationalarchives.gov.uk/20180319114650/http://www.hefce.ac.uk/pubs/yea r/2017/201723/ [Accessed 1 April 2020].

5 For example, here are the revenues for 2017-18 published by the 10 universities surveyed: Oxford University ( $£ 53 \mathrm{~m})$, Queen’s University Belfast ( $222.1 \mathrm{~m})$, University College London ( $£ 14.7 \mathrm{~m})$, University of Sheffield $(£ 12.7 \mathrm{~m})$, University of Cambridge $(£ 8.1 \mathrm{~m})$, University of Leeds $(£ 4.9 \mathrm{~m})$, King’s College London $(£ 2.83 \mathrm{~m})$, University of Edinburgh $(£ 2.39 \mathrm{~m})$, Newcastle University (£1.76m), City, University of London (£397,000): see the webpage at https://www.hesa.ac.uk/data-and-analysis/providers/business-community/table-4d [Accessed 1 April 2020].

6 BBC Radio 4, “University Businesses", (February 2019), The Bottom Line, https://www.bbc.co.uk/programmes/m0002cgm. See also the webpage at https://epsrc.ukri.org/newsevents/multimedia/ppnottinghamrollsroyce/ [Both accessed 1 April 2020].

See the webpage https://www.wipo.int/sme/en/documents/academic_patenting.html [Accessed 1 April 2020].

8 See the webpage https://www.city.ac.uk/research/research-and-enterprise/getting-started/cityschemes/london-city-incubator [Accessed 1 April 2020]. 


\begin{tabular}{|c|c|}
\hline & $\begin{array}{l}\text { As a sample of } 10 \text { UK research intensive universities, the below links to the IP policies of the } \\
\text { University of Oxford, the University of Cambridge, University College London, King's } \\
\text { College London, the University of Sheffield, Newcastle University, the University of Leeds, } \\
\text { Queen's University Belfast and the University of Edinburgh, demonstrate this intention: } \\
\text { https://www.ox.ac.uk/students/academic/guidance/intellectual-property?wssl=1; } \\
\text { https://www.enterprise.cam.ac.uk/intellectual-property/; https://www.ucl.ac.uk/library/ucl- } \\
\text { copyright-advice/ucl-staff-ipr-policy; } \\
\text { https://www.kcl.ac.uk/governancezone/Research/Intellectual-Property-Commercial- } \\
\text { Exploitation-and-Financial-Benefit; https://www.sheffield.ac.uk/rs/commercialisation; } \\
\text { https://www.ncl.ac.uk/media/wwwnclacuk/research/files/NU\%20IP\%20policy\%20effective\%2 } \\
\text { 01-8-18\%20with\%20all\%20links\%20and\%20appendices\%2011-9-18.pdf; } \\
\text { http://www.leeds.ac.uk/secretariat/documents/ipr_policy.pdf; } \\
\text { https://www.qub.ac.uk/Business/Commercialisation/IP-and-innovation/IP-policy/; } \\
\text { https://www.ed.ac.uk/files/imports/fileManager/University-Policy-on-Exploitation-of- } \\
\text { Intellectual-Property.pdf [All accessed 1 April 2020]. }\end{array}$ \\
\hline 10 & $\begin{array}{l}\text { See for example Queen's University IP Policy s.10 and s.14; University of Edinburgh IP } \\
\text { Policy s.3(3); Newcastle University IP Policy s.5; Newcastle University IP Policy s.3(2); City, } \\
\text { University of London IP Policy s.5; University of Oxford IP policy (Statute XVI: Property, } \\
\text { Contracts, and Trusts) (2002) s.5.(1)(a);UCL Policy Statement on Intellectual Property } \\
\text { Rights/Copyright in relation to staff ss.3-5. University of Cambridge IP Policy ss.5-8. KCL } \\
\text { Code of Practice for Intellectual Property, Commercial Exploitation and Financial Benefits } \\
\text { (2016) ss.1-2. }\end{array}$ \\
\hline 11 & $\begin{array}{l}\text { University of Oxford IP policy s.5.(1)(b); UCL Intellectual property rights: policy for students; } \\
\text { KCL Code of Practice for Intellectual Property, Commercial Exploitation and Financial } \\
\text { Benefits (2016) ss.1-2. }\end{array}$ \\
\hline 12 & $\begin{array}{l}\text { University of Oxford IP policy s.5(3); UCL Intellectual property rights: policy for students. } \\
\text { University of Cambridge IP Policy s.14. KCL Code of Practice for Intellectual Property, } \\
\text { Commercial Exploitation and Financial Benefits (2016) ss.1-2. }\end{array}$ \\
\hline 13 & $\begin{array}{l}\text { See for example City, University of London IP Policy ss.8-9; University of Oxford IP policy } \\
\text { ss.6-8; UCL Policy Statement on Intellectual Property Rights/Copyright in relation to staff s.2. } \\
\text { University of Cambridge IP Policy; KCL Code of Practice for Intellectual Property, } \\
\text { Commercial Exploitation and Financial Benefits (2016) s.14. It is notable that despite } \\
\text { universities commonly asserting rights over course materials, Rahmatian states that lecture } \\
\text { slides are likely to fall outside of the typical "course of employment" and thus should remain } \\
\text { the property of the lecturer along with the academic's scholarly publications. See A. } \\
\text { Rahmatian, (2015) "University academics as employees and creators of copyright works: } \\
\text { university academics as owners of copyright?" (2015) 37 E.I.P.R. 355 355, } \\
\text { http://eprints.gla.ac.uk/107291/7/107291.pdf [Accessed 1 April 2020]. }\end{array}$ \\
\hline 14 & $\begin{array}{l}\text { University of Oxford Regulations for the Administration of the University's Intellectual } \\
\text { Property Policy (2002) ss.1-2; UCL Policy Statement on Intellectual Property } \\
\text { Rights/Copyright in relation to staff s.6. University of Cambridge IP Policy ss.2 and 4; KCL } \\
\text { Code of Practice for Intellectual Property, Commercial Exploitation and Financial Benefits } \\
\text { (2016) s.14. }\end{array}$ \\
\hline & \\
\hline
\end{tabular}




\begin{tabular}{|c|c|}
\hline 16 & $\begin{array}{l}\text { Nikita Gabdullin, PhD Electrical Engineering, City, University of London; see the webpages at } \\
\text { https://www.city.ac.uk/research/research-and-enterprise/getting-started/city-schemes/london- } \\
\text { city-incubator. See also the webpages at https://www.city.ac.uk/business-services/case- } \\
\text { studies/heliex-power; https://www.city.ac.uk/law/careers/pro-bono-professional/start-ed [All } \\
\text { accessed } 1 \text { April 2020]; for example Queen's University IP Policy s.13 and s.28(a); Newcastle } \\
\text { University IP Policy s.5(9). }\end{array}$ \\
\hline 17 & $\begin{array}{l}\text { See University of Oxford Regulations for the Administration of the University's Intellectual } \\
\text { Property Policy (2002) ss.1-2; KCL Code of Practice for Intellectual Property, Commercial } \\
\text { Exploitation and Financial Benefits (2016) ss.6-7. }\end{array}$ \\
\hline 18 & Queen's University IP Policy s.33; City, University of London IP Policy s.10. \\
\hline 19 & $\begin{array}{l}\text { See for example art.7(2)(b) of the previous City, University of London IP Policy (2014). KCL } \\
\text { Code of Practice for Intellectual Property, Commercial Exploitation and Financial Benefits } \\
\text { (2016) ss.8-11. }\end{array}$ \\
\hline 20 & $\begin{array}{l}\text { See the webpage at } \\
\text { https://publications.parliament.uk/pa/cm201213/cmselect/cmsctech/348/348.pdf [Accessed } 1 \\
\text { April 2020]. }\end{array}$ \\
\hline 21 & $\begin{array}{l}\text { See for example the previous City, University of London IP Policy (2014) s.7(3)(a) (the same } \\
\text { rule is provided by the current IP Policy). On the management of conflict of interest scenarios, } \\
\text { see also Appendix B of Newcastle University IP Policy s.3(11). }\end{array}$ \\
\hline 22 & $\begin{array}{l}\text { See for example the previous City, University of London IP Policy (2014) s.7(7)(a) (the same } \\
\text { rule is provided by the current IP Policy). }\end{array}$ \\
\hline 23 & $\begin{array}{l}\text { See for example the previous City, University of London IP Policy (2014) s.7(7)(b) (the same } \\
\text { rule is provided by the current IP Policy). }\end{array}$ \\
\hline 24 & $\begin{array}{l}\text { See for example the previous City, University of London IP Policy (2014) s.7(6)(b) (the same } \\
\text { rule is provided by the current IP Policy). }\end{array}$ \\
\hline 25 & UCL Guidance to Staff on IPR issues s.9. \\
\hline 26 & See the Schedule of City, University of London, IP Policy. \\
\hline 27 & KCL University IP Policy s.9. \\
\hline 28 & Oxford University IP Policy s.7(4). \\
\hline 29 & University College London (UCL) Revenue Sharing Policy Statement s..3. \\
\hline 30 & University of Cambridge IP Policy - Schedule. \\
\hline 31 & $\begin{array}{l}\text { See again art.8(1)(a) of the previous City, University of Lond } \\
\text { rule is provided by the current IP Policy); UCL Intellectual pr }\end{array}$ \\
\hline
\end{tabular}


32 C. Dahlborg, D. Lewensohn, R. Danell and C.J. Sundberg, "To invent and let others innovate: a framework of academic patent transfer modes" (2017) 42 Journal of Technology Transfer $538,538$.

33 J. West, A. Salter, W. Vanhaverbeke and H. Chesbrough, "Open innovation: The next decade" (2014) 43 Research Policy 805.

34 O. Gassmann, E. Enkel and H. Chesbrough, "The future of open innovation" (2010) 40 R\&D Management 212.

35 See the webpage at http://www.sheffield.ac.uk/news/nr/university-spin-out-company-withsebastian-conran-to-develop-next-generation-of-robots-1.576135 [Accessed 1 April 2020].

36 See the webpage at www.oxbotica.ai [Accessed 1 April 2020].

37 Clive Cookson, “Oxford Nanopore value reaches £1.5bn as it taps Asia-Pacific funding” (20 March 2018), https://www.ft.com/content/df80e218-2b85-11e8-a34a-7e7563b0b0f4 [Accessed 1 April 2020].

38 See also Amedeus Capital Press Release of 14 April 2015, at https://www.amadeuscapital.com/congenica-genome-diagnostic-company-raises-2-2m; Business Weekly, "What drives the success of Cambridge genomics biotech pioneer Congenica?" (14 May 2019), https://www.businessweekly.co.uk/blog/business-weekly-guestblog/what-drives-success-cambridge-genomics-biotech-pioneer-congenica [Both accessed 1 April 2020].

39 See company's website at www.lycotec.com [Accessed 1 April 2020].

40 See the company's website at www.bio-nano-consulting.com [Accessed 1 April 2020].

41 See also www.genengnews.com/topics/drug-discovery/astrazeneca-acquires-spirogen-for-upto-440m [Accessed 1 April 2020].

42 "UK spin-out's engineering modelling can save global compressor industry millions of KW in energy use", Zenoot, https://zenoot.com/articles/feature-uk-spin-outs-engineering-modellingcan-save-global-compressor-industry-millions-of-kw-in-energyuse/?dm_i=23GR,6U2WF,Q93FI4,REG10,1 [Accessed 22 April 2020].

43 See University of Manchester's press release of 14 October 2014, https://www.manchester.ac.uk/discover/news/article/?id=13069 [Accessed 1 April 2020].

44 See University of Cardiff press release of 30 March 2015; see also the webpage www.ncub.co.uk/success-stories/ultravision.html [Accessed 1 April 2020].

45 See www.sofinnova.fr/nucana-biomed-secures-10-4-million-series-a-financing-to-accelerateits-protide-anti-cancer-drugs-into-clinical-development [Accessed 1 April 2020]. 


\begin{tabular}{|c|c|}
\hline 46 & $\begin{array}{l}\text { See UK Business Angels Association, Clyde Biosciences Closes Series A Investment, } 22 \text { August } \\
\text { 2019, at www.ukbaa.org.uk/news/clyde-biosciences-closes-series-a-investment [Accessed } 1 \\
\text { April 2020]. }\end{array}$ \\
\hline 47 & $\begin{array}{l}\text { See BBC News, “Major deal for AI drug discovery firm Exscientia” (22 March 2019), } \\
\text { http://www.bbc.com/news/uk-scotland-scotland-business-47667125 [Accessed } 1 \text { April 2020]. }\end{array}$ \\
\hline 48 & $\begin{array}{l}\text { Dahlborg, Lewensohn, Danell and Sundberg, "To invent and let others innovate" (2017) } 42 \\
\text { Journal of Technology Transfer 538, 538. }\end{array}$ \\
\hline 49 & $\begin{array}{l}\text { F.J. Cantu-Ortiz, N. Galeano, P. Mora-Castro and J. Fangmeyer Jr, "Spreading academic } \\
\text { entrepreneurship: Made in Mexico" (2017) } 60 \text { Business Horizons } 541 .\end{array}$ \\
\hline 50 & $\begin{array}{l}\text { Instituto de Investigaciones Juridicas de la UNAM, Foro Internacional sobre la Propiedad } \\
\text { Intelectual, Mesa 4, "La Propiedad Intelectual Universitaria" (2014), } \\
\text { https://www.juridicas.unam.mx/videoteca/evento/foro-internacional-sobre-la-propiedad- } \\
\text { intelectual/2014-09-26/mesa-4-la-propiedad-intelectual-en-las-universidades [Accessed } 1 \\
\text { April 2020]. }\end{array}$ \\
\hline 51 & $\begin{array}{l}\text { This statement has been confirmed by the specialists attending the above-mentioned forums in } \\
\text { May } 2018 \text { and } 2019 \text { organised by the Institute of Juridical Research (UNAM) and City, } \\
\text { University of London. There is an ongoing debate regarding what the public universities } \\
\text { should make available for the public; given that they manage public funds, it is believed that } \\
\text { they are bound by the transparency law to make their research outcomes free and publicly } \\
\text { available. However, in the above forums it was noted that the obligation of transparency of the } \\
\text { management of the public funds should not be confused with a total "open access" policy for } \\
\text { all the research outcomes. }\end{array}$ \\
\hline 52 & $\begin{array}{l}\text { See World Intellectual Property Organization, “Frequently Asked Questions: IP Policies for } \\
\text { Universities and Research Institutions", https://www.wipo.int/about- } \\
\text { ip/en/universities_research/ip_policies/faqs/index.html [Accessed } 1 \text { April 2020]. }\end{array}$ \\
\hline 53 & $\begin{array}{l}\text { M.G. Calderón-Martínez and J. Garcia-Quevedo, "Transferencia de conocimiento y } \\
\text { diagnóstico sobre determinantes en la producción de patentes en universidades públicas } \\
\text { mexicanas”, XVII Congreso Internacional de Contaduría Administración e Informática } \\
\text { (2012), http://premio.investiga.fca.unam.mx/docs/ponencias/2012/1.1.pdf [Accessed } 22 \text { April } \\
\text { 2020]. }\end{array}$ \\
\hline 54 & $\begin{array}{l}\text { M.G. Calderón-Martínez and J. García-Quevedo, "Knowledge transfer and university patents } \\
\text { in Mexico" (2013) } 26 \text { Revista Latinoamericana de Administración } 33 .\end{array}$ \\
\hline 55 & $\begin{array}{l}\text { Calderón-Martínez and García-Quevedo, "Knowledge transfer and university patents in } \\
\text { Mexico" (2013) } 26 \text { Revista Latinoamericana de Administración } 33 .\end{array}$ \\
\hline 56 & $\begin{array}{l}\text { See the North American Free Trade Agreement (NAFTA), } 1 \text { January 1994; Agreement on } \\
\text { Trade-Related Aspects of Intellectual Property Rights (TRIPS), } 15 \text { April 1994. Several } \\
\text { intellectual property specialists in Mexico stressed this point in the interviews conducted for } \\
\text { this research. }\end{array}$ \\
\hline
\end{tabular}




\begin{tabular}{|c|c|}
\hline 57 & $\begin{array}{l}\text { J. Aboites and M. Soria, Economía Del Conocimiento y Propiedad Intelectual, Lecciones Para } \\
\text { La Economía Mexicana (México Siglo XXI, 2008). }\end{array}$ \\
\hline 58 & $\begin{array}{l}\text { A. Guzmán, N. Molina Velasco, G. Calderón Martínez, 'Factors affecting the propensity of } \\
\text { academic researchers in Mexico to become inventors and their productivity” (2019) } 64 \\
\text { Contaduría y Administración: Especial Innovación } 1 .\end{array}$ \\
\hline 59 & $\begin{array}{l}\text { According to the Economy Ministry of Mexico, from } 2013 \text { to 2018, UNAM presented } 299 \\
\text { patent applications. See Secretaria de Economía, "Universidades y centros de investigación } \\
\text { nacionales que registran más patentes en México (13 February 2019), } \\
\text { https://www.gob.mx/se/articulos/universidades-y-centros-de-investigacion-nacionales-que- } \\
\text { registran-mas-patentes-en-mexico?idiom=es [Accessed } 1 \text { April 2020]. There is no hard data } \\
\text { regarding the number of academic patents that have been licensed or are in use in the local } \\
\text { economy; nevertheless, several innovation key agents interviewed for this article agree that the } \\
\text { number is very low in comparison to the patents granted. }\end{array}$ \\
\hline 60 & $\begin{array}{l}\text { M.G. Calderón-Martínez, La Gestión de Patentes Universitarias: El Caso de La UNAM } \\
\text { (DGEI-UNAM, 2013). }\end{array}$ \\
\hline 61 & $\begin{array}{l}\text { Federal Labor Law of Mexico (last amended 2019) art.163, } \\
\text { http://www.diputados.gob.mx/LeyesBiblio/pdf/125_020719.pdf [Accessed } 1 \text { April 2020]. }\end{array}$ \\
\hline 62 & $\begin{array}{l}\text { Science and Technology Law (Ley de Ciencia y tecnología) art.13, } \\
\text { http://www.diputados.gob.mx/LeyesBiblio/pdf/242_081215.pdf [Accessed } 22 \text { April 2020]. }\end{array}$ \\
\hline 63 & $\begin{array}{l}\text { CONACYT is the Spanish acronym for the National Council of Science and Technology. It } \\
\text { was created in 1970, as an autonomous and decentralised Council. In } 2019 \text {, the Government of } \\
\text { Lopez Obrador suggested to add the term "Humanities" as part of the name to enhance this } \\
\text { area of research in the country. At the moment of writing, this has not been implemented. }\end{array}$ \\
\hline 64 & $\begin{array}{l}\text { See "Criterios especificos de evaluación, área VII: Ingenierías' Specific criteria for } \\
\text { evaluation, VII área: Engineer, CONACYT (2019), https://www.conacyt.gob.mx /index.php/el- } \\
\text { conacyt/sistema-nacional-de-investigadores/marco-legal/criterios-sni/13720-criterios- } \\
\text { especificos-avii/file [Accessed } 22 \text { April 2020]. }\end{array}$ \\
\hline 65 & $\begin{array}{l}\text { Cantu-Ortiz, Galeano, Mora-Castro and Fangmeyer Jr, "Spreading academic entrepreneurship" } \\
\text { (2017) } 60 \text { Business Horizons } 541 .\end{array}$ \\
\hline 66 & $\begin{array}{l}\text { National Autonomous University of Mexico (UNAM), Regulation on extraordinary income } \\
\text { art.27, } \\
\text { http://www.abogadogeneral.unam.mx:6060/legislacion/view/39/ingreso\%20extraordinario } \\
\text { [Accessed } 1 \text { April 2020]. }\end{array}$ \\
\hline 67 & $\begin{array}{l}\text { Regulation on extraordinary income, National Autonomous University of Mexico (UNAM), } \\
\text { Regulation on extraordinary income art.27, } \\
\text { http://www.abogadogeneral.unam.mx:6060/legislacion/view/39/ingreso\%20extraordinario } \\
\text { [Accessed } 1 \text { April 2020]. }\end{array}$ \\
\hline 68 & $\begin{array}{l}\text { See Instituto Tecnológico y de Estudios Superiores de Monterrey (ITESM), https://tec.mx } \\
\text { [Accessed } 1 \text { April 2020]. }\end{array}$ \\
\hline
\end{tabular}




\begin{tabular}{|c|c|}
\hline 69 & Cantu-Ortiz et al., "Spreading academic entrepreneurship" (2017) 60 Business Horizons 541. \\
\hline 70 & Cantu-Ortiz et al., "Spreading academic entrepreneurship" (2017) 60 Business Horizons 541. \\
\hline 71 & Cantu-Ortiz et al., "Spreading academic entrepreneurship" (2017) 60 Business Horizons 541. \\
\hline 72 & Cantu-Ortiz et al., "Spreading academic entrepreneurship" (2017) 60 Business Horizons 541. \\
\hline 73 & $\begin{array}{l}\text { M. Ballesca Ramírez and Gobierno de Jalisco Secretaría de Promoción Económica, } \\
\text { "Desarrollo Económico de Jalisco, Retrospectiva y Retos"(2013), } \\
\text { http://comunidadmexicana.org.mx/documents/Libro_Desarrollo_Economico_de_Jalisco_retros } \\
\text { pectiva_retos.pdf [Accessed } 1 \text { April 2020]. }\end{array}$ \\
\hline 74 & $\begin{array}{l}\text { Larisa Cruz is, at the moment of writing, the Director of Intellectual Property within the } \\
\text { Ministry of Innovation, Science and Technology of Jalisco. }\end{array}$ \\
\hline 75 & $\begin{array}{l}\text { Ley de Ciencia, Desarrollo Tecnológico e Innovación del Estado de Jalisco, Science, } \\
\text { Technology Development and Innovation Law of Jalisco (2014), } \\
\text { https://transparencia.info.jalisco.gob.mx/sites/default/files/Ley\%20de\%20Ciencia\%20Desarrol } \\
\text { lo\%20Tecnologico\%20e\%20Innovacion.pdf [Accessed } 1 \text { April 2020]. }\end{array}$ \\
\hline 76 & $\begin{array}{l}\text { P. Romo, “Jalisco Se Consolida Como Capital de La Innovación” (9 February 2016), El } \\
\text { Economista, https://www.eleconomista.com.mx/estados/Jalisco-se-consolida-como-capital-de- } \\
\text { la-innovacion-20160209-0113.html [Accessed } 1 \text { April 2020]. }\end{array}$ \\
\hline 77 & $\begin{array}{l}\text { Acronym of the Mexican Association for the protection of Intellectual Property (Asociación } \\
\text { Mexicana para la Protección de la Propiedad Intelectual). }\end{array}$ \\
\hline 78 & $\begin{array}{l}\text { Acronym for the National Association of Enterprise lawyers (Asociación Nacional de } \\
\text { Abogados de Empresa). }\end{array}$ \\
\hline 79 & $\begin{array}{l}\text { Acronym for the Mexican Institute of Industrial Property (Instituto Mexicano de Propiedad } \\
\text { Industrial). }\end{array}$ \\
\hline 80 & $\begin{array}{l}\text { See Y. Alfaro, "La estrategia de Guadalajara para ser el Silicon Valley de Latinoamérica” (26 } \\
\text { December 2017), Entrepreneur, https://www.entrepreneur.com/article/290658; Sonia Corona, } \\
\text { "El Silicon Valley mexicano está en Jalisco" (12 March 2017), El País, } \\
\text { https://elpais.com/tecnologia/2017/03/12/actualidad/1489275848_767120.html [Both accessed } \\
1 \text { April 2020]. }\end{array}$ \\
\hline 81 & $\begin{array}{l}\text { P. Romo, “Jalisco Es El Segundo Estado Con Más Patentes e Invenciones de México” (19 } \\
\text { May 2019), El Economista, https://www.eleconomista.com.mx/estados/Jalisco-es-el-segundo- } \\
\text { estado-con-mas-patentes-e-invenciones-de-Mexico-20190519-0028.html [Accessed } 1 \text { April } \\
\text { 2020]. Mexico is divided into } 32 \text { states. }\end{array}$ \\
\hline 82 & $\begin{array}{l}\text { Participants of the forums included representatives of the Intellectual Property Office of } \\
\text { Mexico, patent lawyers from leading Mexican IP law firms, TTOs representatives and } \\
\text { researchers from several Mexican universities. }\end{array}$ \\
\hline
\end{tabular}


83 For instance, the Government of Jalisco has an agreement with the local patent office aimed at speeding up patent applications where stakeholders are part of the programmes (the procedure should not exceed two years).

84 In 2019 there has been a proposal from CONACYT concerning changes in the National Law of Science and Technology, in order to build a repository that publishes all outcomes of the research fund by the Council. The scientific community has been debating this proposal before the Parliament, so that they may acknowledge the positive and negative sides of this. See "Memorias Conversatorio para el análisis del Sistema Nacional de Ciencia, Tecnología e Innovación", Report of the Dialogue for the análisis of the National System of Science, Technology and Innovation, Foro Consultivo Científico y Tecnológico (2019), https://foroconsultivo.org.mx/FCCyT/libros_editados/conversatorio_sistema_cti.pdf [Accessed 22 April 2020].

85 This challenge was also identified by the Asociación Mexicana de Inversión de Impacto (Mexican Association for Impact Investment) in the report of Impact Investment in Mexico, published in 2018, available at https://nvgroup.org/inversion-de-impacto-en-mexico [Accessed 22 April 2020].

86 Dahlborg, Lewensohn, Danell and Sundberg, "To invent and let others innovate" (2017) 42 Journal of Technology Transfer 538, 538. 